IRA-International Journal of Education \&

Multidisciplinary Studies

QUARTERLY

ISSN 2455-2526; Vol.16, Issue 04 (Oct.-Dec., 2020)

Pg. no. 209-216.

Institute of Research Advances

https://research-advances.org/index.php/IJEMS

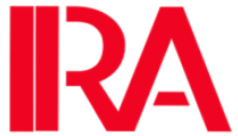

\title{
Daniel Defoe on the Issue of Prostitution: A Critical Exploration of Roxana The Fortunate Mistress
}

\author{
Alidou Razakou Ibourahima Boro ${ }^{1 \#}$, Alexis Hergie Seguedeme ${ }^{2}$ \\ ${ }^{1}$ University of Parakou, R. Benin. \\ ${ }^{2}$ University of Abomey- Calavi, Benin.
}

\# corresponding author

Type of Work: Peer-Reviewed

DOl: http://dx.doi.org/10.21013/jems.v16.n4.p1

\section{How to cite this paper:}

Boro, A., Seguedeme, A. (2020). Daniel Defoe on the Issue of Prostitution: A Critical Exploration of Roxana The Fortunate Mistress. IRA International Journal of Education and Multidisciplinary Studies (ISSN 2455-2526), 16(4), 209-216. DOI: http://dx.doi.org/10.21013/jems.v16.n4.p1

(c) Institute of Research Advances.

This work is licensed under a Creative Commons Attribution-NonCommercial 4.0 International License subject to a proper citation to the publication source of the work.

Disclaimer: The scholarly papers as reviewed and published by the Institute of Research Advances (IRA) are the views and opinions of their respective authors and are not the views or opinions of the IRA. The IRA disclaims of any harm or loss caused due to the published content to any party.

Institute of Research Advances is an institutional publisher member of Publishers International Linking Association Inc. (PILA-CrossRef), USA. The institute is an institutional signatory to the Budapest Open Access Initiative, Hungary advocating the open-access of scientific and scholarly knowledge. The Institute is a registered content provider under Open Access Initiative Protocol for Metadata Harvesting (OAI-PMH).

The journal is indexed \& included in WorldCat Discovery Service (USA), CrossRef Metadata Search (USA), WorldCat (USA), OCLC (USA), Open J-Gate (India), EZB (Germany) Scilit (Switzerland), Airiti (China), Bielefeld Academic Search Engine (BASE) of Bielefeld University, Germany, PKP Index of Simon Fraser University, Canada. 


\begin{abstract}
Prostitution is said to be one of the world's oldest jobs. It is a social phenomenon with various root causes. Poverty, unemployment, and sometimes the necessity to do something to survive are some of the causes of prostitution. This activity is not without consequences for the practitioners. I have decided to critically explore Daniel Defoe's Roxana the Fortunate Mistress to find out the reasons behind some women practicing such an activity. The study mainly focuses on the behaviour of the characters Roxana in the two novels. The main aim of the study is to put stress on the consequences of prostitution and draw the attention of the young generation on the dangers of prostitution and provide them with pieces of advice on the benefits of adopting decent behaviour. Based on psychoanalysis and feminism as literary theories, I conclude that prostitution is often linked to materialism and female greed.
\end{abstract}

Keywords: Prostitution; Roxana; critical exploration; Roxana the Fortunate Mistress

\title{
Introduction
}

Prostitution is the business or practice of engaging in sexual activity in exchange for a payment. It is sometimes described as a sexual service commonly referred to euphemistically as "the world's oldest profession". A person who works within this field is called a prostitute or sex worker. In his book legalizing Prostitution (2003), Ronald Weitzer identifies six types of prostitution: Independent call girl, escort agency employee, brothel employee, window workers, bar and casino workers, and streetwalkers. Many women turn to any of the mentioned forms of prostitution due to certain various circumstances and reasons for life. I have selected Moll Flanders and Roxana by Daniel Defoe to back up my study.

The main aim of the study is to put stress on the consequences of prostitution and draw the attention of the young generation on the dangers of prostitution and provide them with pieces of advice on the benefits of adopting decent behaviour. For the study, I decided to investigate and find out the message Defoe's would like to share with the readers about the issue of prostitution. I illustrate some of my comments on the behavior of the main characters of the novel and I got some additional information from field investigation.

\section{1- Theoretical framework}

Feminism and psychoanalysis have been used as essential support of my work. This is due to the different kind of characters involved in the achievement of Look Flanders by Daniel Defoe. In reality, feminist theory has always been about viewing the social world in a way that illuminates the forces that create and support inequality, oppression, and injustice, and in doing so, promotes the pursuit of equality and justice. That said, since the experiences and perspectives of women and girls were historically excluded from social theory and social science, much feminist theory has focused on their interactions and experiences within society to ensure that half the world's population is not left out of how we see and understand social forces, relations, and problems. Also, Psychoanalytic theory is the theory of personality organization and the dynamics of personality development that guides psychoanalysis, a clinical method for treating psychopathology. First laid out by Sigmund Freud in the late 19th 
century, psychoanalytic theory has undergone many refinements since his work. So feminism and psychoanalysis theory play important role in the understanding of the feminism aspect in the novel.

\section{Materials and methods}

For this research work, I have passed through documentary research, and then I went through works dealing with prostitution. I also find it necessary to elaborate on a questionnaire I have addressed to some street prostitutes to find out the reason behind their being street girls. The above method has been used taking into account my understanding of the book under study.

\section{2- Results}

The issue of prostitution has a long time been an issue of great interest. Over the years, famous writers, poets, and scholars have written a lot on prostitution each according to the reality of his period. They have tried through their works to sensitize citizens about the helplessness and sufferings of the modern hooker, who have stumbled upon the profession either by deceit or under dire indigence. As I have earlier, many women become a prostitute because of poverty, unemployment, the necessity of finding something to survive face to life problems and sometimes due to greed and materialism. On the bases of what Roxana faced after the unplanned departure of her husband I could first say that this confirms what she said while warning women by saying:

"if you have any regard to your future happiness; any view of living comfortably with a husband; any hope of preserving your fortunes or restoring them after disaster; never ladies marry a fool" (Defoe 1724 p8)

The above statement indicates that she agrees to get married to a dangerous person. But she was the one who has decided to get married without the consent of her father. She is then the sole to draw the consequences. She was left moneyless with five kids to feed in total starvation. She said:

"The House, that was before handsomely furnish'd with Pictures and Ornaments, Cabinets, PeirGlasses, and everything suitable, was now stripp'd, and naked, most of the Goods having been seiz'd by the Landlord for Rent, or sold to buy Necessaries; in a word, all was Misery and Distress" (Roxana p17)

The conditions are so worse that she decided to take action to reverse the situation. How can a woman without a job, without any qualification, and having five children to feed can handle this kind of situation? She then decided to become a whore.

"Nor was what followed more her own fault than mine, who led her almost into it at first, and quite into it at last; and this may be a farther testimony what a hardness of crime I was now arrived to, 
which was owing to the conviction, that was from the beginning upon me, that I was a whore, not a wife; nor could I ever frame my mouth to call him husband or to say "my husband" when I was speaking of him." (Defoe 1724 p 24)

Turning back to all virtue of married women, she decided to change her social and economic conditions. "Poverty is the strongest Incentive; a temptation, against which no Virtue is powerful enough to stand out" to survive. (Roxana p27) she confessed. She then got involved in a series of criminal activities to reach her goal. She first accepted to become the mistress of her landlord. She fully enjoys the relation; she regularly received presents from her new partner and a guaranty that he would never let her down. After the death of the Jeweler, she decided to offer herself the service of the Prince. "I manag'd him with such Art, that he generally anticipated my Demands" (Roxana p66) she said. Just to show how smart and skillful she is to move from one man to another. She received gifts, money and many presents from the Prince. Roxana becomes rich and independent and powerful. Roxana decided to live her own life, she does not care about any conventional marriage. Her main objective is to gather the maximum of wealth and material to live the way she wants. On this vain she declared:

"that the very Nature of the Marriage-Contract was, in short, nothing but giving up Liberty, Estate, Authority, and everything, to the Man, and woman was indeed, a meer Woman ever after, that is to say a Slave" (Roxana p148).

Marriage or love is a synonym for slavery for her. She chose to live for money and interest in all present or future relationship in which she would get involved.

Daniel Defoe, through the portrait of Roxana would like to draw the attention of the reader to how fast a woman can change when she is pushed to extremity. Most of the time women become prostitutes because of social and economic problems.

My husband has died five years ago. I have many kids. I was helpless. My in-laws were not supporting me. There was nothing to eat for my kids even for one time. Then I started prostitution (Hannon and Defina, 2005)

Defoe showed the readers the power of money and materials in society and how determined women can be in quest of economic independence. Once Roxana manages to reach a level of economic independence, she nevertheless continues to pursue ever more financial success to the point where it becomes less a need to stave off predation by others than to become a predator herself. Consumed by the desire to accumulate, Roxana seems to transform into a more traditional view of immorality as she starts to verge on the precipice of revealing that she is, 
after all, perhaps suffering from an inherent character flaw. And yet, without the early aching to attain independence due to financial setbacks, Roxana could never have reached this status of traditional immorality ${ }^{1}$.

This is not the first work of Defoe about such a topic in Moll Flanders (1722) I almost noticed the same behaviour from the main protagonist, Moll.

Moll Flanders is a story about the fall and rise of a beautiful woman who was born in Newgate Prison. Because she was determined to be someone other than a servant, and because of her great greed, she sought to marry a wealthy man. She married some with money and some without. One of her husbands, she learned to her horror, was her brother, by whom she had several children. Her fear of poverty led her to commit many criminal acts. However, even when she had obtained a large store of cash and goods, she continued stealing.

Her ingenious disguises helped her evade prison for many years, in spite of the fact that a number of her accomplices were caught and hanged or transported to the colonies. Moll's heart hardened as she continued to escape arrest. Greed drove her on until she became known as the richest thief in London. Her "governess," who was at onetime Moll's midwife, became her partner-in-crime and guided her criminal activities. She later grew penitent and devout and remained Moll's loyal friend for many years.

When Moll became less cautious, she was finally captured and taken to Newgate Prison where she was taunted by the other prisoners. Moll repented momentarily as she confessed her crimes to her spiritual adviser, a minister sent by the governess. Because of his intervention, Moll's death sentence was commuted to transportation to the American colonies. While in prison Moll reencountered Jemmy, a highwayman who was her most recent living husband. She persuaded him to join her on the ship transporting convicts to the colonies. This they accomplished and settled in Maryland, where they became successful plantation owners in about a year's time.

In Virginia, Moll's former husband-brother was living with one of their sons. Moll was anxious to receive her inheritance from her mother's estate and to meet her son but was equally reluctant to confront her brother. Everything turned out all right for Moll: she was able to get her inheritance, she was able to avoid her brother, and she met her son, who proved to be devoted and fair. At the age of almost seventy, Moll returned with Jemmy to London, where they planned to live out their lives in repentance for their criminal activities. ${ }^{2}$

As you can Roxana is not so different from Moll in Moll Flanders by Daniel Defoe. For the love of money and life commodities, Moll was able to get married to many men all of them because of their richest. She has been able to get married with her husband younger brother to keep enjoying the family's wealth.

\footnotetext{
${ }^{1}$ Sexton, Timothy. "Roxana: The Fortunate Mistress Quotes". GradeSaver, 11 August 2018 Web. 1 July 2020.

${ }^{2}$ Arnez, Nancy Levi. CliffsNotes on Moll Flanders. 29 Jun $2020</$ literature/m/moll-flanders/book-summary>.
} 
Indeed, I have preserved the elder brother's bonds to me, to pay \#500, which he offered me for my consent marry his brother, and his with what I had saved of the money he formerly gave me, about as much more by my husband, left me about as much more by my husband; left me a widow with about \#1200 in my pocket (Moll Flanders p70)

Ignoring her dignity and the appreciation of society she gets involved in incest. What matters is how richer and richer is she getting. Becoming a persona un grata a rejected person in the society is not a problem. She declared:

That as my sister-in-law at Colchester had said, beauty, wit, manners, sense, good humour, good behaviour, education, virtue, piety, or any other qualification, whether of body or mind, had no power to recommend; that money only made a woman agreeable; that men chose mistresses indeed by the gust of their affection, and it was requisite to a whore to be handsome, well-shaped, have a good mien and a graceful behaviour; but that for a wife, no deformity would shock the fancy, no ill qualities the judgment; the money was the thing; the portion was neither crooked nor monstrous, but the money was always agreeable, whatever the wife was. (Defoe,1722)

The most important thing is the power of money. Being the mistress of a man does not matter. Provided you profit from what he possesses. Money is what a man should pursue; love is just a game she believed."I had been tricked once by that Cheat called love, but the Game was over..." (Defoe, 1722)

Love is just a game, and now the game is over.

for though I had no great scruples of conscience, as I have said, to struggle with, yet I could not think of being a whore to one brother and a wife to the other (Defoe 104)

Moll explains through this statement that even though she'll do whatever it takes to get what she wants, she still has her limits and she knows what they are. This quote highly focuses on the theme of morality where Moll knows that having a relationship with two brothers at the same time is wrong. Meaning that she is conscious that what she as doing is not morally good. In the end, she asks for repentance. We resolve to spend the remainder of our years in sincere penitence. (Defoe 1722)

Repentance is an important element of the novel. Time and again Moll professes her shame and regret over her wicked ways, but time and again she indulges in immoral behavior. It is only in times of financial stability that she even considers whether her lifestyle might have consequences. While the novel ends with Moll's desire to atone for her sins, this desire coincides with her age Moll is in her seventies, and hence opportunities for wickedness are likely few and far between and relative wealth. Throughout, the novel seems to suggest that repentance, like 
morality, is the privilege of the rich, and never quite answers whether her remorse is real, or but a narrative stance necessary to make the novel acceptable reading material in 18th-century English society. In other words, even her remorse seems tainted with opportunism. ${ }^{3}$

It also happens that women whose mother's relatives and friends are in prostitution enter into prostitution. This may be considered as getting involved in prostitution because of a bad environment and favorable family conditions.

"Society is responsible in making me prostitute. My friend involved me in prostitution when I came to know, it had happened and now I'm realizing day by day." (Hughes, 2004)

The social environment can be responsible for women getting involved in prostitution.

\section{3- Critical analysis}

Published in 1724 by legendary author Daniel Defoe, the novel that has come to be known simply as Roxana is actually an example of the 18th century trend toward excessively long titles. Roxana is much like Moll Flanders is that her "wickedness" is presented not as an inherent moral lacking, but as the circumstances of economic necessity. Roxana engages in a series of love affairs for the express purpose of ensuring her own domestic equality and financial stability. Love rarely if ever enters into the calculus. ${ }^{4}$ The issue of prostitution also call on the notion of gender discrimination, social injustice and economic problems. Actions have to be taken to support women in their love relation. Roxana got married with a man who does not allow her to talk, to give her point of view. He is always right on every issue of their couple life. He rarely shares his projects and company problems with his wife. Roxana was totally under the domination of her "fool" as she said. He has left home without any word for his five kids and to a lovely wife. What can we expect from a woman without any job any support from his family as well as her husband family members? She was obliged to find easy ways and means to survive. I agree that she did more than what she is expected to do. She becomes a whore and an unsatisfied woman. Her desire the have the maximum of wealth and live an independent life without any care for her own children is condemnable. Life is made of a series of difficulties but whatever the case, one should never abandon his kids for a so called independent life. No one is born a prostitute but life circumstances could lead to prostitution. Women need to be treated with more care to avoid such a regrettable situation.

\section{Conclusion}

The root causes of prostitution vary from woman to woman. According to the social and economic difficulties each woman faces. Based on each one's belief and perception of the issue, some may blame women for that while others may show understanding. A closer reading of Daniel Defoe's Roxana maybe somehow useful to

\footnotetext{
${ }^{3}$ https://www.coursehero.com/lit/Moll-Flanders/quotes/

"Tabor, Mason. "Roxana: The Fortunate Mistress Study Guide: Analysis". GradeSaver, 5 June 2019 Web. 1 July 2020.
} 
readers to better understand the hidden face of prostitution and the consequences that go with it. It is difficult to judge women without entering their lives and understanding the situation that draws them to become a prostitute. What I can suggest is to call on men and women to be responsible for his acts

\section{References}

[1]. Arnez, Nancy Levi. Cliffs Notes on Moll Flanders. 29 Jun 2020

[2]. Daniel Defoe The fortune mistress, UK 1724.

[3]. Daniel Defoe Moll Flanders, UK 1722.

[4]. Hannon and Defina, 2005, violent crime in African American and White neighborhood: Is poverty's detrimental effect race-specific? Journal of poverty, 9(3), DOI:10.1300/J134V09n03-O3

[5]. Sexton, Timothy. Roxana: The Fortunate Mistress Quotes. GradeSaver, 11 August 2018 Web. 1 July 2020.

[6]. Tabor, Mason. Roxana: The Fortunate Mistress Study Guide: Analysis. Grade Saver, 5 June 2019 Web. 1 July 2020. 